\title{
Developmental and tissue-specific regulation of $\beta$-tubulin gene expression in the embryo of the sea urchin Strongylocentrotus purpuratus
}

\author{
Patricia Harlow and Martin Nemer \\ The Institute for Cancer Research, Fox Chase Cancer Center, Philadelphia, PA 19111 USA
}

\begin{abstract}
Four $\beta$-tubulin mRNAs in the embryo of the sea urchin Strongylocentrotus purpuratus are transcribed from at least 3 of the 9-12 $\beta$-tubulin genes. A $\beta 1$ tubulin mRNA of $1.8 \mathrm{~kb}$, transcribed from a unique $\beta 1$ gene, is expressed with high specificity in the pluteus ectoderm. Another 1.8-kb mRNA, $\beta 2$, and a 2.5-kb $\beta 3$ mRNA are moderately ectoderm specific. In contrast, a 3.0-kb $\beta 4$ mRNA is highly specific for the endomesoderm tissue fraction. Certain similarities in developmental and tissue-specific expression suggest that these $\beta$-tubulin genes may be related in their mode of regulation to counterparts among the genes for actin, another cytoskeletal protein. Measurements of absolute amounts revealed a distinct developmental profile for each $\beta$-tubulin mRNA. An increase in the total amount of $\beta$-tubulin mRNA in the early blastula was correlated with an increase in transcription rate per nucleus; whereas, later in the mesenchyme blastula stage, the $\beta$-tubulin mRNA level decreased sharply as the rate of $\beta$-tubulin gene transcription on a per embryo basis remained constant. Thus, during development through the blastula stages, there was a switch to a predominantly posttranscriptional regulation of $\beta$-tubulin mRNA expression, probably through a decrease in mRNA stability.
\end{abstract}

[Key Words: $\beta$-Tubulin mRNAs; sea urchin embryo; tissue specificity; developmental gene expression; transcription rate; quantification method]

Received November 17, 1986; revised version received and accepted December 18, 1986.

Tubulins, the major proteins of microtubules, are the basis for the construction of mitotic spindles, cilia, flagella, and cell-shape determinants. The primary sequences of both $\alpha$ - and $\beta$-tubulins are highly conserved (Alexandraki and Ruderman 1983; Cleveland and Sullivan 1985; Harlow and Nemer, in prep.|, nevertheless, individual tubulin genes in many cases are expressed differentially (Burland et al. 1984; Natzle and McCarthy 1984; Alexandraki and Ruderman 1985). The expression of functionally different polypeptides is suggested by the identification of conserved variable-region sequences that seem to define four distinct isotypes (Sullivan and Cleveland 1986). However, there is no example of an exclusive cell type specificity for any $\alpha$ - or $\beta$-tubulin gene (Cleveland and Sullivan 1985), except in the case of a divergent erythrocyte $\beta$-tubulin (Murphy and Wallis 1983). Thus, it has been difficult to demonstrate clearcut associations between individual tubulins and specific cellular functions. In addition, such diversity of gene function is excluded in organisms that contain a single $\alpha$ - or $\beta$-tubulin gene (Callahan et al. 1984) or identical multiples of these genes (Brunke et al. 1984).

The expression of tubulin multigene families (Cleveland et al. 1980; Alexandraki and Ruderman 1981) may be studied advantageously in the embryogenesis of sea urchins, whose various aspects of development are known in great detail (Czihak 1975; Davidson 1986; Giudice 1986). Several tubulin mRNAs are present in the eggs of the species Lytechinus pictus and the expression of tubulin mRNAs is developmentally regulated, as evidenced by increases in their levels during development to the blastula stage (Alexandraki and Ruderman 1985). These increases are correlated with an overall increase in translatable tubulin mRNA (Infante and Heilman 1981; Alexandraki and Ruderman 1985| and an increase in tubulin protein synthesis (Harkey and Whiteley 1983). Cell-type changes become evident later in the gastrula, where tubulins are preferentially synthesized in the epithelial cells, but not in the primary mesenchyme cells (Harkey and Whitely 1982). Synthesis of tubulin restricted in this manner has not been previously related to the expression of specific tubulin genes in the embryo.

Morphogenesis of the sea urchin blastula requires increased microtubule synthesis for the formation of $\mathrm{mi}$ totic spindles and cilia. To analyze how tubulin gene expression is regulated and quantitatively related to these processes in embryogenesis, we have set out to characterize the tubulin gene transcripts expressed during this and subsequent periods of development. In later embry- 

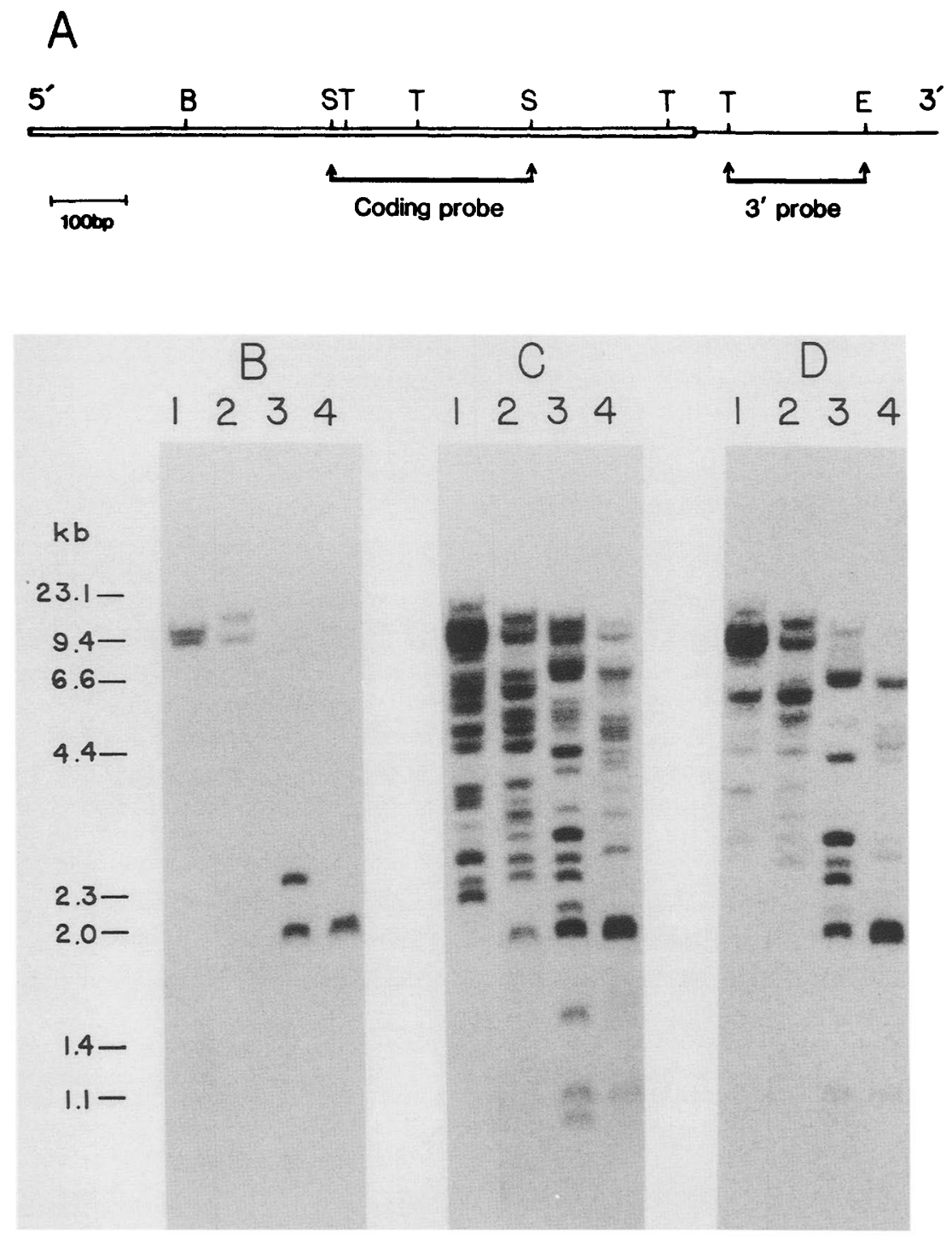

Figure 1. The $\beta$-tubulin genes detected on gel blots of genomic DNA restriction fragments by probes derived from the $\beta 1 \mathrm{cDNA}$. $(A)$ A partial restriction map of the $\beta 1 \mathrm{cDNA}$ is shown with its 880 -bp coding region (open box) and 320 bp of $3^{\prime}$ untranslated region (line) and the locations of the coding-region probe and the $\beta 13^{\prime}$-specific probe fragment. Restriction sites are: (B) BgIII; (S) SacI; (T) TaqI; and (E) EcoRI. (B) The $\beta 13$ '-probe was hybridized with the sperm DNA of two individuals digested with HindIII (lanes 1 and 2) or EcoRI (lanes 3 and 4) at high stringency. The coding-region probe was hybridized with a replica blot and washed at moderate stringency $(C)$ and later at high stringency $(D)$.

onic stages, tubulin in microtubules and actin in microfilaments are among the cytoskeletal proteins of differentiated cells. The expression of members of the actin gene family in Strongylocentrotus purpuratus has been shown to be cell-type specifically regulated (Cox et al. $1986)$. Hence, we have asked whether the $\beta$-tubulin genes might also be expressed under tissue-specific regulation, and thus are potentially coordinated with the expression of genes encoding other cytoskeletal proteins. To perform these analyses, we have made use of a $\beta$-tubulin cDNA (Sp- $\beta 1$ ) of $S$. purpuratus (Harlow and Nemer, in prep.) to construct specific and general $\beta$-tubulin probes for detecting and quantifying the $\beta$-tubulin genes and their transcripts, and to develop an accurate gel blot method for measuring absolute quantities of specific RNA transcripts.

\section{Results and discussion}

The $\beta$-tubulin gene family of S. purpuratus

Fragments of $\beta 1$ cDNA as probes to distinguish $\beta$-tubulin genes The many examples of 3 ' untranslated regions serving as gene-specific probes (Bond et al. 1984; Lee et al. 1984; Elliot et al. 1985; Lewis et al. 1985a,b) led us to construct a $\mathrm{Sp}-\beta 1$-specific probe from the EcoRI-TaqI fragment in the $3^{\prime}$ untranslated region of the $\beta 1$ cDNA (Fig. 1A). In contradistinction, all of the $\beta$-tubulin genes could be detected by a probe for the 
coding region (Cleveland et al. 1980; Alexandraki and Ruderman 1981). Although $\alpha$-tubulin and $\beta$-tubulin gene sequences generally fail to cross-hybridize in other systems (Cleveland et al. 1980; Alexandraki and $\mathrm{Ru}$ derman 1981), we, nevertheless, minimized high local homology by choosing the SacI-SacI fragment as a $\beta$-tubulin coding-region probe. Its homolog in the $\beta 3$ tubulin of $L$. pictus, when compared with $\alpha$-tubulin sequences of the same species, showed only $8 \%$ amino acid homology, and less than $35 \%$ nucleotide homology, much below the minimum of $50-55 \%$ homology that will allow cross-hybridization even at low stringency (Jones et al. 1979; Sim et al. 1979; Jones and Kafatos 1982). The probe derived from the EcoRI-TaqI fragment in the $3^{\prime}$ untranslated region of $S p-\beta 1$ is designated the $\beta 13^{\prime}$-specific probe, while the probe derived from the SacI-SacI fragment of the $\beta$-tubulin coding-region is designated the coding-region probe.

$A$ single $\beta 1$-tubulin gene exists in the $\beta$-tubulin multigene family To characterize the $\beta 1$-tubulin genes by restriction fragment analysis, the genomic DNA from each of several individuals was digested with either $H$ HindIII or EcoRI, gel-blotted, and hybridized with the $\beta 1$ 3 '-specific probe. In all cases, two of which are shown in Figure 1B, at most two bands hybridized. Since the genome of $S$. purpuratus is highly polymorphic (Britten et al. 1978) and probes for unique genes usually react with two different restriction fragment alleles in any individual sperm DNA preparation (Thomas et al. 1982; Posakony et al. 1983; Lee et al. 1984), our results suggest the presence of a unique $\beta 1$ tubulin gene. In contrast, hybridization of the coding-region probe with the genomic DNAs of these same individuals revealed up to 20 bands with extensive polymorphism (Fig. 1C). Cleveland et al. (1980) similarly detected about 20 bands by probing HindIII-digested $S$. purpuratus DNA with a chicken $\beta$ tubulin cDNA. These results, obtained with either the heterologous or the homologous coding probe, suggest about $10 \beta$-tubulin genes in this species. All but three to six of the multiple bands detected by hybridization with the coding-region probe can be eliminated by increasing the stringency of washing (Fig. 1D). Of those remaining, one to two correspond to $\beta 1$; hence two to four bands represent two genes different from $\beta 1$ but having a high degree of homology to $\beta 1$ in this part of the coding region.

To determine the precise number of $\beta 1$ genes, as well as the number of genes in the $\beta$-tubulin family, the same two probes were hybridized with known amounts of genomic DNA on slot blots relative to standards consisting of varying amounts of a plasmid DNA, containing both probe sequences. Densitometric analysis of two individuals indicated 0.8 and 0.9 copies of the $\beta 1$ gene per haploid genome (Fig. 2A). Therefore, a single $\beta 1$ gene is present in the $S$. purpuratus genome. In contrast, there are a total of about $11 \beta$-tubulin genes per haploid genome, since hybridization with the coding-region probe indicated 9 and 12 genes for these same individuals (Fig. 2B). A similar range $(11-13)$ has been esti- mated for the $\beta$-tubulin family of another sea urchin, $L$. pictus (Alexandraki and Ruderman 1981). When the blot hybridized with the coding-region probe was washed using high stringency conditions (Fig. 2C), a total of three to four genes remained. Since there is one $\beta 1$ gene per haploid genome, two to three other genes are $\beta 1$-like in that they resemble the $\beta 1$ gene in this part of the coding region more closely than the other $\beta$-tubulin genes; however, since at high stringency the $\beta 13^{\prime}$ probe does not hybridize to these genes, they are distinct from $\beta 1$. These genes plus $\beta 1$ constitute a subclass of $\beta$-tubulin genes.

\section{Characterization of $\beta$-tubulin $m R N A$ s expressed in embryos}

Detecting and distinguishing individual $\beta$-tubulin mRNAs To characterize the $\beta$-tubulin gene transcripts, we successively hybridized the $\beta 13^{\prime}$-specific probe and the coding probe to gel blots of total embryo RNA from two developmental stages. The $\beta 13^{\prime}$-specific probe hybridized with a single 1.8 -kb RNA band in both the blastula and pluteus stages (Fig. 3). The coding-region probe, however, detected bands of 1.8 and $2.5 \mathrm{~kb}$ in RNA from blastulae, and these bands together with a third band of $3.0 \mathrm{~kb}$ in RNA from pluteus larvae. Long autoradiographic exposures showed no hybridization of

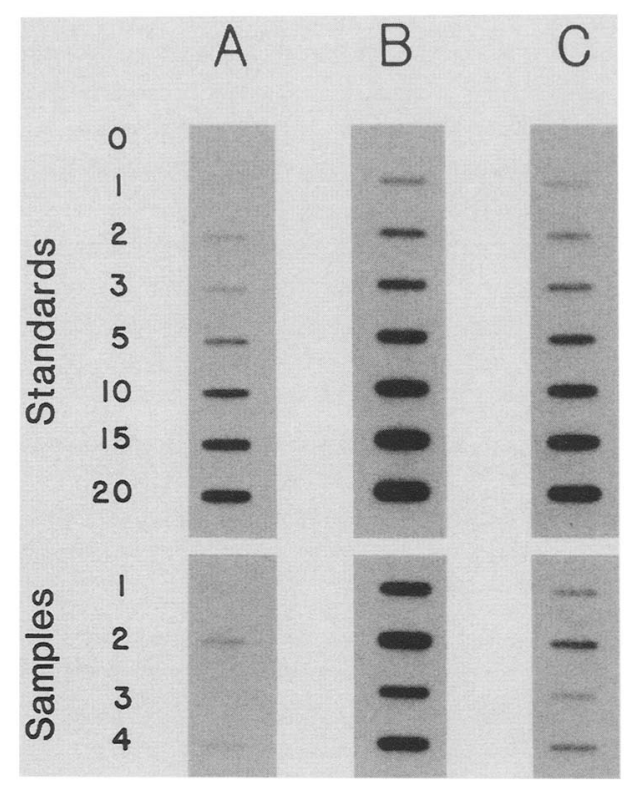

Figure 2. Estimation of $\beta$-tubulin gene number in $S$. purpuratus genomic DNA. Nitrocellulose slot blots were prepared by loading two different genomic DNAs as samples and the indicated haploid genome equivalents of linearized pSP64- $\beta 1$-Ref DNA as standards. $(A)$ One blot was hybridized with the $\beta 1$ 3 '-specific probe and washed at high stringency. On this blot sample rows 1 and 3 contain $1 \mu \mathrm{g}$, while rows 2 and 4 contain 3 $\mu \mathrm{g}$ of PstI-digested genomic DNA. (B) Another blot was hybridized with the coding-region probe and washed at moderate stringency. On this blot rows 1 and 3 contain $0.5 \mu \mathrm{g}$, while rows 2 and 4 contain $1 \mu \mathrm{g}$ of Pst I-digested genomic DNA. $(C)$ The blot from $B$ was washed at high stringency. 

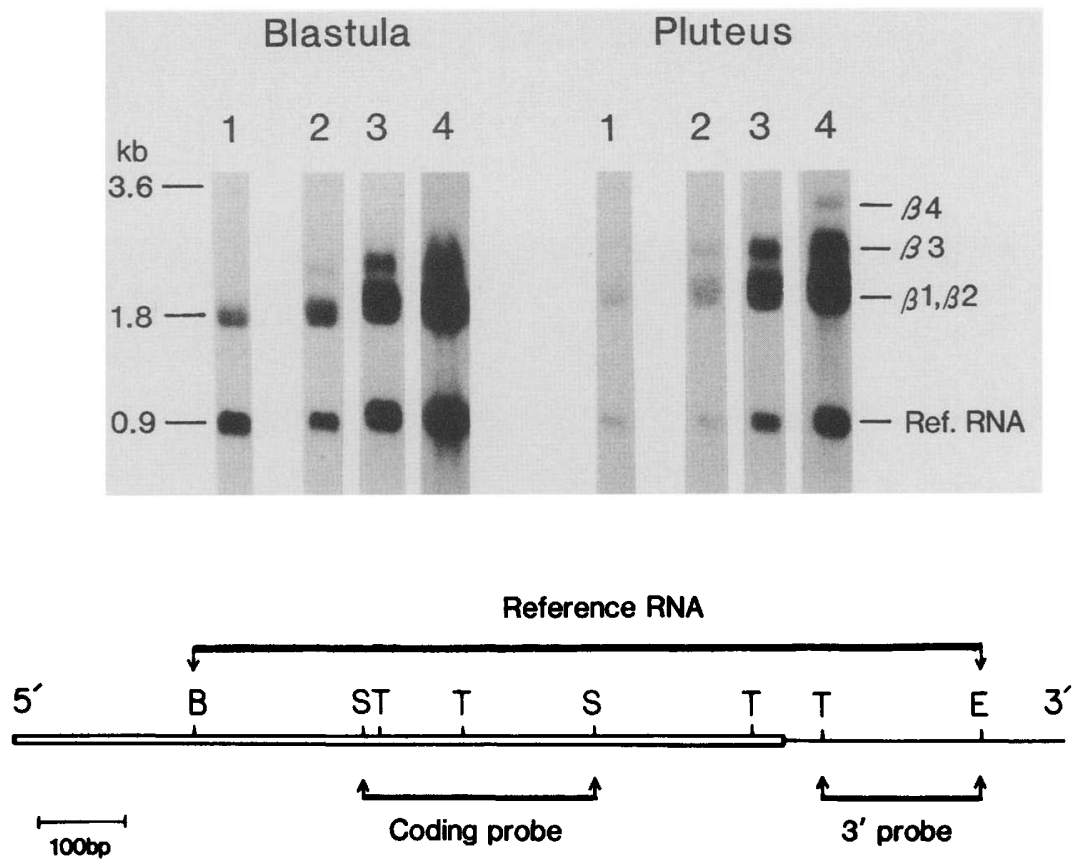

Figure 3. Detection of distinct $\beta$-tubulin mRNAs on a gel blot of total RNA from early- and late-stage embryos. A mixture of total RNA (7 $\mu \mathrm{g} /$ lane) from blastulae and plutei and $250 \mathrm{pg}$ and $62.5 \mathrm{pg}$, respectively, of ${ }^{3} \mathrm{H}$-labeled reference RNA, were electrophoresed and transferred to nitrocellulose. The gel blot was hybridized successively with the $\beta 13^{\prime}$-specific probe (lane 1) and then with the coding-region probe (lanes 2-4) as described in Materials and methods. Lanes 1 and 2 are 4-hr exposures, while lanes 3 and 4 are 12and $60-\mathrm{hr}$ exposures, respectively. Illustrated below is a partial restriction map of $\beta 1 \mathrm{cDNA}$ and the locations of the sense-strand reference RNA and the anti-sense coding and 3 'probes.

$\beta 13^{\prime}$-specific probe with the 2.5- or 3.0-kb RNAs (data not shown).

We next asked whether the $\beta 1$ mRNA accounted for all or only part of the RNA in the $1.8-\mathrm{kb}$ band. If the $1.8-\mathrm{kb}$ band consisted only of $\beta 1 \mathrm{mRNA}$, then the probes from the coding and $\beta 13^{\prime}$-specific regions of this mRNA would hybridize to this band in equimolar proportions. If other species were present together with $\beta 1$ mRNA, then an additional amount of hybridization of the coding-region probe would reflect the amount of the other species. These alternatives can be distinguished by measuring the successive hybridization of the two probes with the sample RNA relative to a reference containing both the probed sequences, $\beta 13$ '-specific and coding, in a (necessarily) $1: 1$ molar ratio. For this purpose, a 931-base sense-strand RNA was transcribed in vitro from the BglII-EcoRI fragment of $\beta 1$ cDNA subcloned into SP64 (Fig. 3). Accurately determined amounts of this reference RNA were mixed with RNA samples, gel electrophoresed, and transferred to nitrocellulose. After the gel blot was hybridized with the $\beta 13^{\prime}$ specific probe, the signal in the $1.8 \mathrm{~kb}$ band was compared with the signal for the reference RNA, which migrates well ahead of the $\beta$-tubulin bands, to indicate the molecular equivalent of $\beta 1$ mRNA. After removal of the Bl 3'-specific probe, a similar analysis was performed with the coding-region probe on the same gel blot. Densitometry showed that the molecular equivalent of the coding-region probe hybridized to the $1.8 \mathrm{-kb}$ band, relative to the reference RNA, was greater than three- and greater than twofold more than the molecular equiva- lent of the $\beta 13^{\prime}$ probe hybridized to this band in the blastula and pluteus stages, respectively (Fig. 3, lanes 1 and 2). Therefore, the 1.8-kb band from both developmental stages contains $\beta 1$ RNA plus additional non- $\beta 1$ tubulin mRNA, which we shall designate $\beta 2$. Whether or not $\beta 2$ is a single species remains to be determined. Therefore, in the $S$. purpuratus pluteus there are at least four $\beta$-tubulin mRNAs: $\beta 1(1.8 \mathrm{~kb}), \beta 2(1.8 \mathrm{~kb}), \beta 3(2.5$ $\mathrm{kb})$, and $\beta 4(3.0 \mathrm{~kb})$. These mRNAs are almost entirely poly $(\mathrm{A})^{+}$RNA, since greater than $80 \%$ could be bound to oligo(dT)-cellulose and the hybridization signals in these bands from both probes resisted treatment with ribonuclease A to the same extent (data not shown).

Distinguishing $\beta$-tubulin mRNAs as transcripts of different genes The $\beta 1$ mRNA is clearly distinguished from the other $\beta$-tubulin mRNAs by virtue of its hybridization with a specific probe from its $3^{\prime}$ untranslated sequence. However, it cannot be concluded, strictly on the basis of the differences in their sizes, that the other $\beta$-tubulin mRNAs are transcribed from different genes. To test this proposition, we examined their degrees of homology to the $\beta 1$ coding region, as indicated by differences in melting temperatures of hybrids formed between cach mRNA and the coding-region probe derived from $\beta 1$. The rationalc was that mRNAs transcribed from the same gene would have identical nucleotide sequences in the coding region and that discrepancies betwcen $T_{\mathrm{m}}$ values could arise only if the mRNAs were transcribed from different genes. The coding-region probe was annealed to total pluteus RNA and reference 


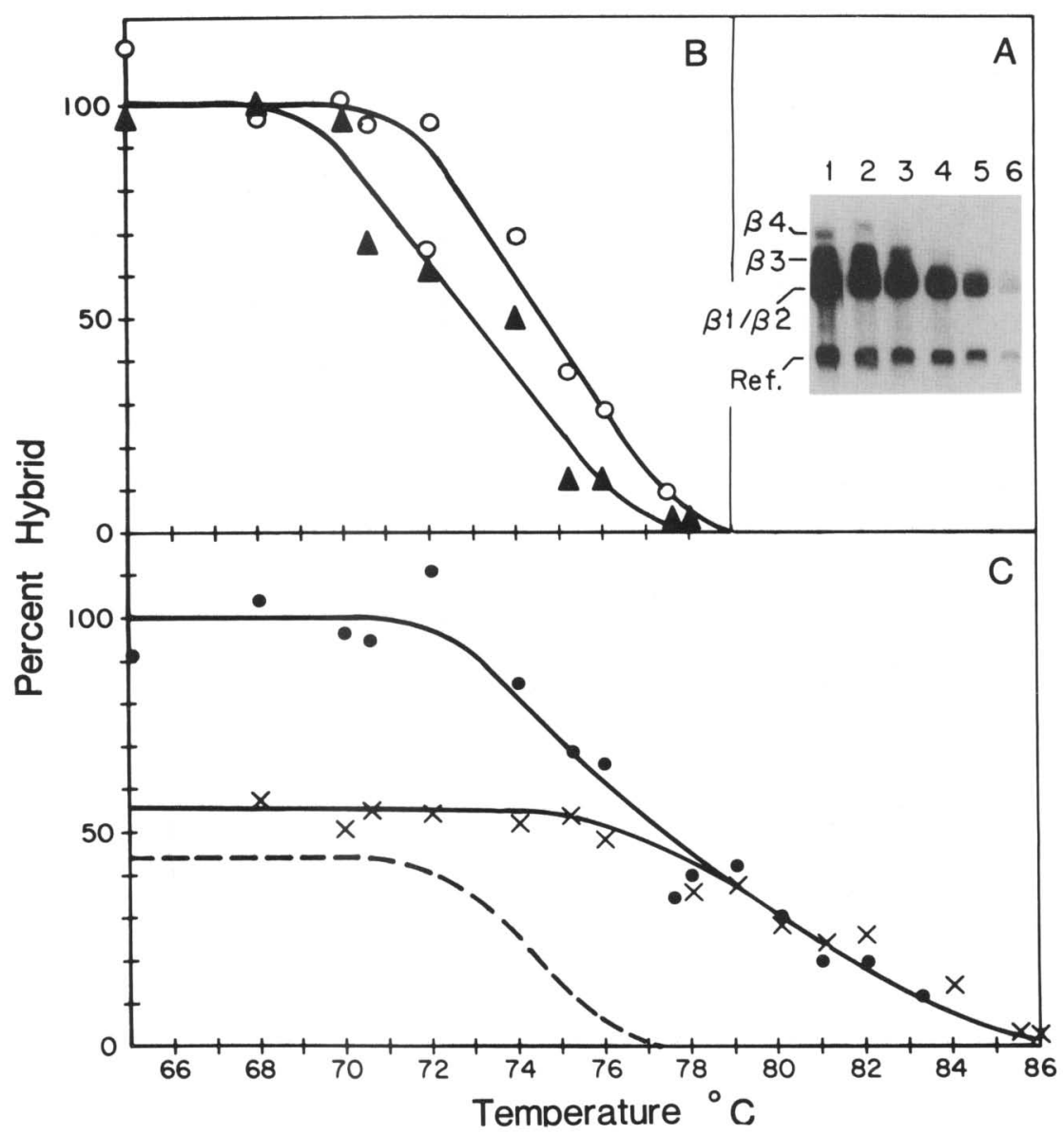

Figure 4. Melting profiles of individual $\beta$-tubulin RNAs. A mixture of pluteus RNA (7 $\mu \mathrm{g} / \mathrm{lane}$ ) and ${ }^{3} \mathrm{H}$-labeled reference RNA (62.5 pg/lane) was applied to 30 lanes and electrophoresed as in Fig. 3 . The gel blots were cut into individual strips for hybridization with the coding-region probe and subsequently washed in $0.1 \times$ SSC at the indicated temperatures. $(A)$ Representative autoradiograms of these strips are shown, in which lanes $1-6$ represent temperatures of $65^{\circ}, 70^{\circ}, 75^{\circ}, 79^{\circ}, 83^{\circ}$, and $85^{\circ} \mathrm{C}$. The amounts of the individual RNAs were determined by densitometer tracing, directly in $B$ for the $\beta 3(O)$ and $\beta 4(\triangle)$ RNAs. C $(C)$ To distinguish $\beta 2$ from $\beta 1$, the melting profile of the $1.8-\mathrm{kb}(\beta 1+\beta 2)$ band $(O)$ was compared with that of the reference RNA (X). Since the melting profile of the reference RNA represents that of $\beta 1$ RNA, the melting profile of $\beta 2$ RNA ( - - $)$ was obtained by subtracting that of the reference RNA $(\beta 1)$ from that of the $1.8-\mathrm{kb}(\beta 1+\beta 2)$ band.

RNA on gel blots, then the probe was melted off at increasing temperatures (Fig. 4). The melting profile of the reference RNA, representing $\beta 1$ mRNA, was subtracted from the profile of the 1.8 -kb RNA $(\beta 1$ plus $\beta 2)$ to give that of $\beta 2$ mRNA. The melting profiles of the $2.5-\mathrm{kb} \beta 3$ and $3.0-\mathrm{kb} \beta 4 \mathrm{mRNAs}$ were obtained directly. The $T_{\mathrm{m}}$ values of the RNA : RNA duplexes are $\beta 1-80.5^{\circ}$, $\beta 2-74.3^{\circ}, \beta 3-74.6^{\circ}$, and $\beta 4-73.0^{\circ} \mathrm{C}$. The $T_{\mathrm{m}}$ values of $\beta 1$ and $\beta 4$ mRNAs are different from each other and from the others. However, the difference for $\beta 2$ and $\beta 3$ mRNAs is not large enough to merit a conclusion concerning their genic origins; although their $T_{m}$ values are similar, they could have different sequences and be transcripts from different genes. Alternatively, $\beta 2$ and $\beta 3$ mRNAs may be derived from the same gene as the result of alternative polyadenylation sites, similar to the 1.8and $2.6-\mathrm{kb}$ RNAs derived from the human M40 $\beta$-tubulin gene (Lee et al. 1983). Until further studies distinguish between these alternatives, the differences in $T_{\mathrm{m}}$ value indicate that at least three different genes are transcribed during the embryonic development of S. purpuratus.

Developmental and tissue-specific regulation of $\beta$ tubulin gene expression

Quantification of $\beta$-tubulin mRNAs The measurement of the molecular equivalents of the $\beta 13^{\prime}$-specific and coding-region sequences by hybridizing each with its respective probe relative to the reference RNA can be used to calculate not only the amounts of the $1.8-\mathrm{kb} \beta 1$ and $\beta 2$ mRNAs, as described above, but also the amounts of the $2.5-\mathrm{kb} \beta 3$ and $3.0-\mathrm{kb} \beta 4$ mRNAs. The wide range of abundances of the $\beta$-tubulin mRNAs was accommodated by varying the amount of reference RNA and the time of autoradiographic exposure. The assay had a standard deviation of $15 \%$. We established that this "reference RNA method" was applicable over a useful abundance range by virtue of the linearity of hybridization signal for each probe in the concentration 


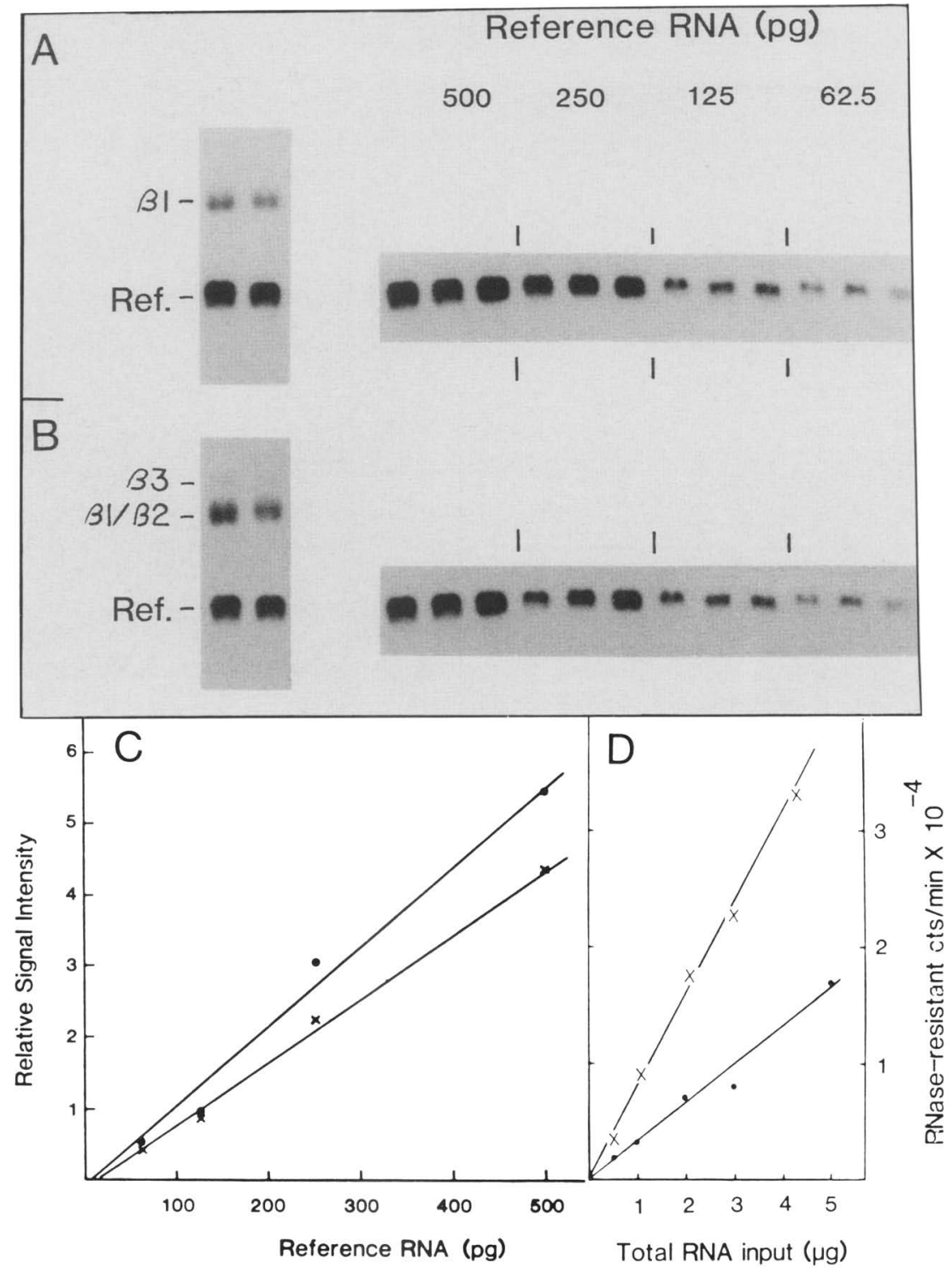

Figure 5. Measurement of the amount of $\beta$-tubulin RNA by the reference RNA method $(A, B$, and $C)$ and the solution hybridization method $(D)$. Mixtures of sample RNA and serial dilutions of reference RNA were electrophoresed, blotted and hybridized successively with the $\beta 13$ '-specific $(A, O)$ and the coding region $(B, X)$ probes as in Fig. 3. Two different blastula samples are shown with their reference RNA bands, which correspond to the first two lanes of the dilution series of reference RNA. $(C)$ The autoradiographs were scanned by densitometry and a standard curve was plotted as hybridization signal for each probe versus the amount of input reference RNA. (D) For measurement by solution hybridization, tracer-excess titrations of the $\beta$-tubulin RNA in the total RNA from 20-hr swimming blastulae were performed using the $\beta 13$ '-specific $(0)$ or coding-region probe $(x)$. After hybridization, the quantity of RNA-RNA duplex was assayed as described in Materials and methods.

range of the $\beta$-tubulin mRNAs in the embryo samples tested. As an example, gel blots are shown for two blastula samples with a series of different amounts of the reference RNA run on the same gel, hybridized successively to the $\beta 13^{\prime}$-specific probe (Fig. $5 \mathrm{~A}$ ) and to the coding-region probe (Fig. 5B). By densitometry we determined that both signals were linear in this range (Fig. $5 \mathrm{Cl}$.

The accuracy of this reference RNA method was tested by comparison with the solution hybridization method as described by Lee et al. (1986). Blastula RNA was hybridized in solution with excess amounts of either probe. Using the slopes derived from plots of the
RNase-resistant counts per minute versus the total RNA input (Fig. 5D), and the specific activities of the $\beta 13^{\prime}$ specific and coding probes (813 and 645 disintegrations/ minute per picogram, respectively, in this experiment), we calculated that this blastula sample contained $1.18 \times 10^{5}$ molecules of $\beta 1 \mathrm{mRNA} / \mathrm{embryo}$ and a total of $2.50 \times 10^{5} \beta$-tubulin mRNA molecules/embryo. Without gene-specific probes, the only additional conclusion we can draw from these measurements, based on solution hybridization procedures, is that the blastula sample contains, besides the $\beta 1$ mRNA, an additional $1.32 \times 10^{5}$ molecules of $\beta$-tubulin mRNA/embryo. However, using the reference RNA method (Fig. 5A,B) 
we determined that this blastula sample contained $1.07 \times 10^{5}, 1.98 \times 10^{5}$, and $0.21 \times 10^{5}$ molecules $/ \mathrm{em}$ bryo of $\beta 1, \beta 2$, and $\beta 3$ mRNAs, respectively, or a total of $3.26 \times 10^{5} \beta$-tubulin mRNA molecules/embryo. The excellent agreement of the $\beta 1$ and total $\beta$-tubulin mRNA values between the two methods indicates that the reference RNA method is at least as accurate as the solution hybridization method.

Concentration of individual $\beta$-tubulin mRNAs in eggs and embryos at various stages of development The relative amounts of the individual $\beta$-tubulin mRNAs in eggs and embryos at different stages are exemplified by the two different developmental series shown in Figure 6. No increase in amount of the $\beta$-tubulin mRNAs is apparent before $9 \mathrm{hr}$; however, their increase in size between 0 and $6 \mathrm{hr}$ can be correlated with polyadenylation, since the percentage of $\beta$-tubulin RNA bound to oligo(dT)-cellulose increased (unpublished data). Accumulation is detected between $9-12 \mathrm{hr}$ postfertilization (morula to early blastula stage). The amounts in the $1.8-\mathrm{kb}(\beta 1$ plus $\beta 2)$ band and the $2.5-\mathrm{kb}$ $\beta 3$ band increase substantially in development from egg to blastula stage. The $\beta 3$ mRNA constitutes a larger proportion of the total at the pluteus stage than at earlier stages. In contrast, $\beta 4$ mRNA is not detected until the gastrula stage, and even then requires a long autoradiographic exposure.

Utilizing the reference RNA method, we measured the amounts of the individual $\beta$-tubulin mRNAs in samples of developmental series from six different batches of embryos. The multiple values for each time point were averaged to yield the values plotted in Figure 7. Each $\beta$-tubulin mRNA displays a distinct developmental profile. The $\beta 1$ and $\beta 2$ mRNAs constitute $96 \%$ of the maternal $\beta$-tubulin mRNA; both are present at $0.13 \times 10^{5}$ molecules per egg, while $\beta 3$ mRNA is at onetenth this value. Accumulation of $\beta 1$ mRNA begins during the morula-blastula transition $(9-10 \mathrm{hr})$ and reaches a maximum value of $1.1 \times 10^{5}$ molecules/embryo at the swimming blastula stage. Thereafter, the amount of this mRNA decreases by about half during development to the gastrula, then increases during development from gastrula to pluteus, again reaching $1.0 \times 10^{5}$ molecules/embryo. Although $\beta 2$ mRNA follows a similar pattern, its peak is slightly earlier at the rotating blastula stage where it reaches a higher value $\left(2.0 \times 10^{5}\right.$ molecules/embryo) than $\beta 1$ mRNA. By the gastrula stage the amount of $\beta 2$ mRNA has decreased to one-fifth of its maximum, becoming similar in amount to $\beta 1 \mathrm{mRNA}$. Later, it increases to $1.7 \times 10^{5}$ molecules/embryo in the pluteus. The developmental profile of $\beta 3$ mRNA resembles that of $\beta 1$ and $\beta 2$ mRNAs in the early-stage embryo, but its levels are significantly lower, reaching only $0.5 \times 10^{5}$ molecules/embryo in the rotating blastula. In contrast to $\beta 1$ and $\beta 2$ mRNAs, which attain their maximum levels in the blastula, the maximum level of $\beta 3$ mRNA $1.2 \times 10^{5}$ molecules/embryol is in the pluteus. Originally at less than $5 \%$ of total $\beta$-tubulin mRNA in the egg, $\beta 3$ mRNA is $30 \%$ of the total at this stage. Even more restricted during development than the other $\beta$-tubulin mRNAs, $\beta 4$ mRNA cannot be detected until the late gastrula stage, after which in the pluteus it reaches a level of $0.11 \times 10^{5}$ molecules/embryo (less than $5 \%$ of total $\beta$-tubulin mRNA). The profile of total $\beta$-tubulin mRNAs displays successive peaks at the blastula and pluteus stages, with an intervening minimum during the gastrula stages (Fig. 7). A similar profile for total $\beta$-tubulin protein synthesis in L. pictus was observed by Alexandraki and Ruderman

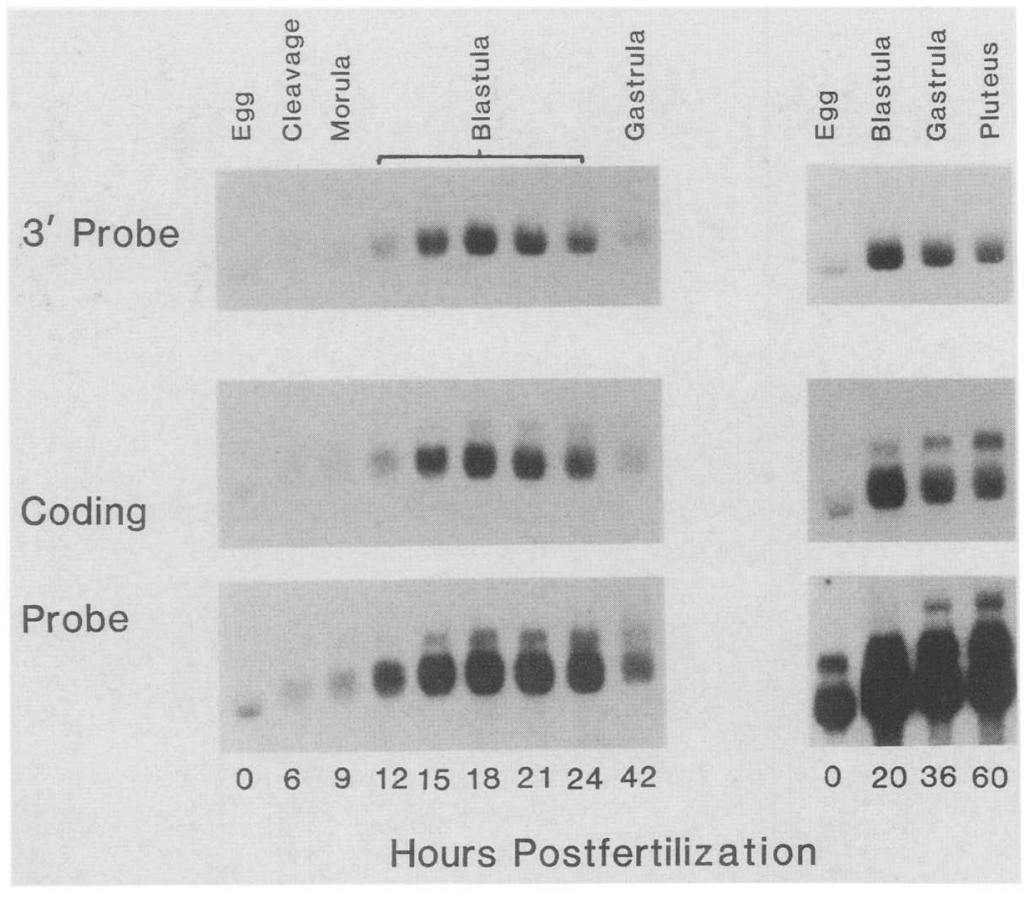

Figure 6. Characterization of $\beta$-tubulin RNAs at different embryonic stages by gel-blot hybridization. Gel blots of total RNA ( $7 \mu \mathrm{g} / \mathrm{lane}$ ) of embryos in a series of developmental stages from separate batches of eggs (right and left panels) were hybridized successively first with the $\beta 13$ '-specific probe, then with the coding-region probe as in Fig. 3. Exposures with the $\beta 13^{\prime}$-specific and the coding probe were $2 \mathrm{hr}$ for the blots on the left and $4 \mathrm{hr}$ for the blots on the right. Longer exposures are presented of the blots with the coding probe: $4 \mathrm{hr}$ on the left to show the egg and cleavage stages and $44 \mathrm{hr}$ on the right to show the $\beta 4$ RNA. 
(1981). Their subsequent description (1985) of two distinct $\beta$-tubulin mRNAs also revealed increases from the egg to blastula stage, but did not correspond in later stages to the profiles we have observed with $S$. purpuratus.

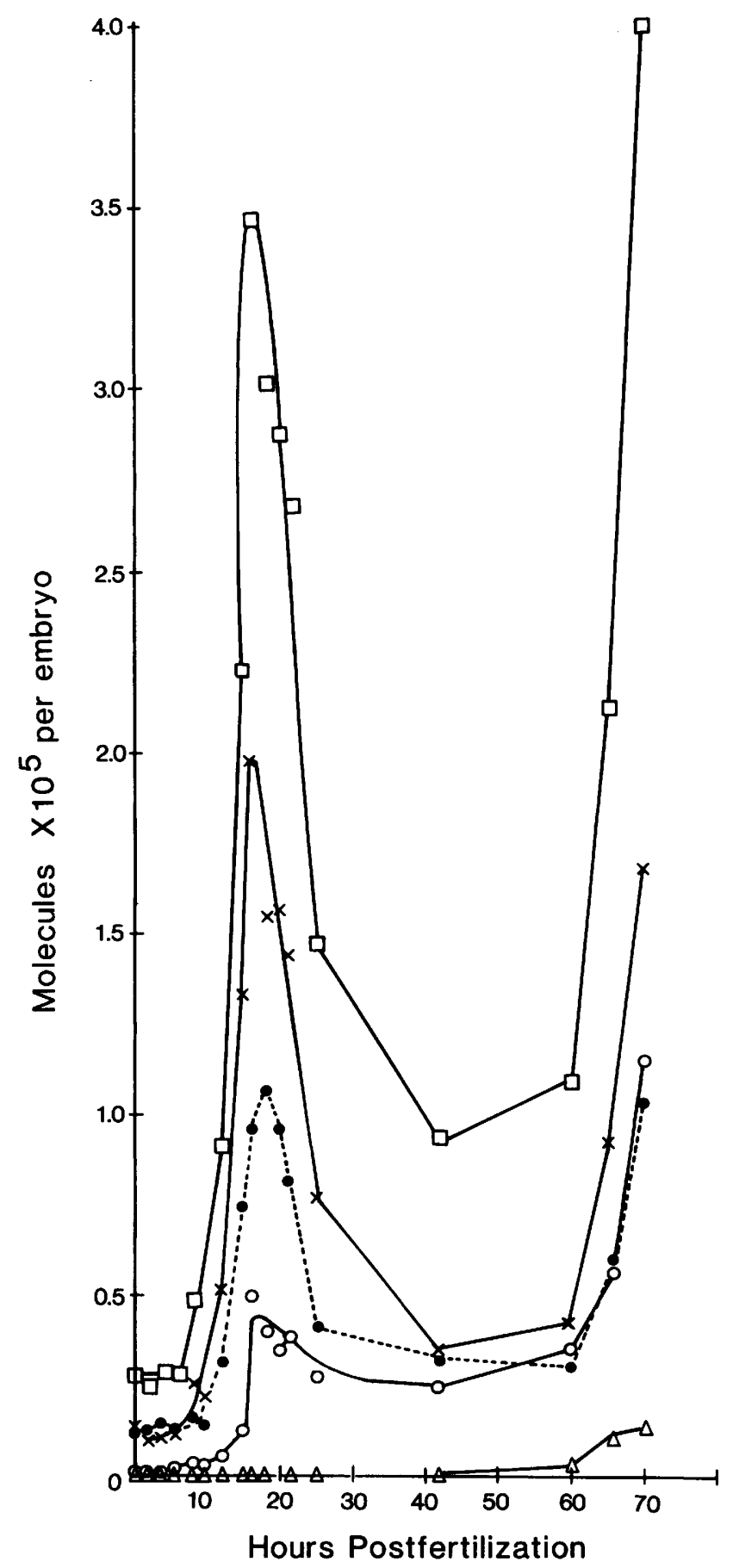

Figure 7. Quantitative changes of $\beta$-tubulin mRNAs during development. Developmental profiles of $\beta 1(0), \beta 2(x), \beta 3(0)$, and $\beta 4(\Delta)$ RNAs, were obtained by determining the amount of these RNAs in samples from six different developmental series using the reference RNA run on the same Northern as a standard as in Figs. 3 and 5. The amounts of the four RNAs were summed to obtain the total amount of $\beta$-tubulin RNA ( $\square$ ).
Rates of $\beta$-tubulin synthesis correlated with $\beta$-tubulin $m R N A$ concentrations The rate of $\beta$-tubulin protein synthesis also increases substantially during development. From the rates of total protein synthesis in S. purpuratus of 250 and $550 \mathrm{pg} / \mathrm{hr}$ at, respectively, the cleavage and blastula stages (Goustin and Wilt 1981), and total microtubule protein synthesis being $0.4 \%$ and $1 \%$ of total protein synthesis at these respective stages, measured by Raff and Kaumeyer (1973) in Arbacia punctulata, we estimate that the rate of $\beta$-tubulin protein synthesis increases from $0.5 \mathrm{pg} / \mathrm{hr}$ at cleavage to 2.8 $\mathrm{pg} / \mathrm{hr}$ in the blastula. Since the 1335 bases of the $\beta$-tubulin-coding region should contain about 10 ribosomes (Brandis and Raff 1978; Whiteley and Mizuno 1981) with an elongation rate of 1.8 amino acids/sec per ribosome (Goustin and Wilt 1981; Martin and Miller 1983), the $0.3 \times 10^{5} \beta$-tubulin mRNA molecules/embryo in late cleavage would synthesize about $0.4 \mathrm{pg}$ of $\beta$-tubulin protein/hr per embryo, while the $3 \times 10^{5} \beta$-tubulin mRNA molecules in the hatched blastula would synthesize about $3.6 \mathrm{pg}$ of $\beta$-tubulin protein $/ \mathrm{hr}$ per embryo. The reasonable agreement in these respective rates, based on independent measurements and assumptions, suggests that all $\beta$-tubulin mRNAs are fully engaged in protein synthesis at the stages under consideration. This agreement and the observation that tubulin mRNAs are associated entirely with polysomes at these stages in $L$. pictus (Alexandraki and Ruderman 1985) support the conclusion that the developmental changes in $\beta$-tubulin mRNA levels reflect changes in $\beta$-tubulin synthesis.

Transcription rates during early developmental stages To test whether the initial increase in $\beta$-tubulin mRNA concentration is regulated at the level of transcription, we examined run-on transcripts from nuclei prepared at each of three early embryonic stages: $6 \mathrm{hr}$ cleavage, $12-\mathrm{hr}$ early blastula, and 23 -hr mesenchyme blastula (Fig. 8). The in vitro-labeled RNA was hybridized to SP64- $\beta 1$-Ref DNA, which comprises $75 \%$ as $\beta 1$ coding region and $25 \%$ as $\beta 13^{\prime}$ untranslated sequence, and thus represented total $\beta$-tubulin transcription. The inclusion of heparin during the labeling of nuclei allowed primarily the elongation of transcripts (Groudine et al. 1981), thus reflecting either the number of RNA polymerase molecules specifically involved or the rate of transcription. In contrast to histone gene transcription, which was substantial in nuclei from the cleavage-stage embryos and considerably diminished in the $12-\mathrm{hr}$ blastula (data not shown), the rate of $\beta$-tubulin gene transcription per nucleus relative to the 6 -hr cleavage stage increased 20 -fold between 6 and $12 \mathrm{hr}$, and then declined by the $23 \mathrm{rd}$ hr to $40 \%$ of the 12 -hr value. It is not known whether this average decline per nucleus, associated with an increase in cell number from 200 to 500 per embryo, reflects an overall decrease in nuclear rate or unequal rates for different cells of the mesenchyme blastula. In either case, the $\beta$-tubulin transcription rate per embryo (rate per nucleus times cell number per embryo) does not change during subsequent development through the 12- to 23-hr blastula stages. Consequently, the overall contribution of newly transcribed $\beta$-tubulin 
RNA must be taken as constant when evaluating changes in $\beta$-tubulin mRNA metabolism during the blastula stages.

A developmental shift in mode of regulation The striking accumulation of total $\beta$-tubulin mRNA in the 10 - to $16-\mathrm{hr}$ early blastula contrasts with the subsequent, sharp decrease in the 20 - to 25 -hr mesenchyme blastula (Fig. 7). The increased rate of $\beta$-tubulin gene transcription during the cleavage-early blastula transition indicates that the early-stage accumulation of $\beta$-tubulin mRNA is transcriptionally regulated. However, the constancy of the overall $\beta$-tubulin transcription rate during the subsequent early and late blastula stages indicates that the decline in concentration of $\beta$-tubulin mRNA in the mesenchyme blastula cannot be attributed predominantly to a change in the rate of synthesis, but to post-transcriptional events. We conclude that there is a developmental shift in the predominant mode of regulation from transcriptional to post-transcriptional.

The decline of total $\beta$-tubulin mRNA in the mesenchyme blastula can be caused by a change in RNA processing and/or degradation. By examining two extreme possibilities we can suggest limits for the stability of $\beta$ tubulin mRNA in the late blastula. If there is a sudden failure of processing to yield new mRNA molecules, then the net loss of total $\beta$-tubulin mRNA in the mesenchyme blastula would reflect in its slope of decay (Fig. 7) a $t_{1 / 2}$ of $5 \mathrm{hr}$ for the preexisting mRNA molecules, a value similar to that of the average mRNA in the embryo (Nemer et al. 1975; Galau et al. 1977). On the other hand, if all $\beta$-tubulin transcripts are processed and the $\beta$-tubulin mRNAs are stable during the early blastula period, then their accumulation rate of $0.64 \times 10^{5}$ molecules/hr per embryo (Fig. 7) can be taken as their synthetic rate. Since the total $\beta$-tubulin transcription rate is the same in the early blastula and mesenchyme blastula, this synthetic rate and the rate of loss of $0.34 \times 10^{5}$ molecules/hr per embryo in the mesenchyme blastula can be used to calculate a decay rate of $0.98 \times 10^{5}$ molecules/hr per embryo and a $t_{1 / 2}$ of $70 \mathrm{~min}$ for $\beta$-tubulin mRNA at this stage. The shift in the regulation of total $\beta$-tubulin mRNA expression during development through the blastula stages may involve a change from negligible turnover of these mRNAs to a $t_{1 / 2}$ having a minimum value of $1 \mathrm{hr}$ and a maximum of $5 \mathrm{hr}$.

Changes in stability of tubulin mRNAs have been demonstrated in several systems where tubulin synthesis is modulated, e.g., following deflagellation of Chlamydomonas reinhardi (Baker et al. 1984), the cell cycle in Physarum (Schedl et al. 1984), and the differentiation of a teratocarcinoma cell line (Howe et al. 1984). Furthermore, the destabilization of tubulin mRNAs has been implicated in the decrease in tubulin synthesis, correlated with an enlarged pool of depolymerized subunits in colchicine-treated, tissue culture cells (Cleveland and Havercroft 1983; Caron et al. 1985). Since the peak concentration of $\beta$-tubulin mRNA in the sea urchin blastula occurs at the end of the major period of rapid cell division and ciliogenesis, an overshoot in $\beta$-tu- bulin synthesis with the accumulation of unpolymerized subunits is possible. An autoregulatory mechanism involving tubulin mRNA stability may thus be operative not only in colchicine-treated cells, but also normally in the late-stage sea urchin blastula.

Tissue specificity of the $\beta$-tubulin $m R N A$ s We determined the distribution of the four $\beta$-tubulin mRNAs in pluteus larvae, utilizing the tissue fractionation procedure of McClay and Chambers (1978) and the reference RNA method. From four experiments, of which Figure 9 is an example, we calculated for each $\beta$-tubulin mRNA mean values of molecules per unit RNA mass in each tissue fraction. The ratio of these values was taken as the specific enrichment for each mRNA. The $\beta 1$ mRNA is highly ectoderm specific, since its amount in this tissue fraction is 17 -fold higher than in the endomesoderm fraction. The $\beta 2$ and $\beta 3$ mRNAs are also enriched in the ectoderm, but only about five- and threefold, re-
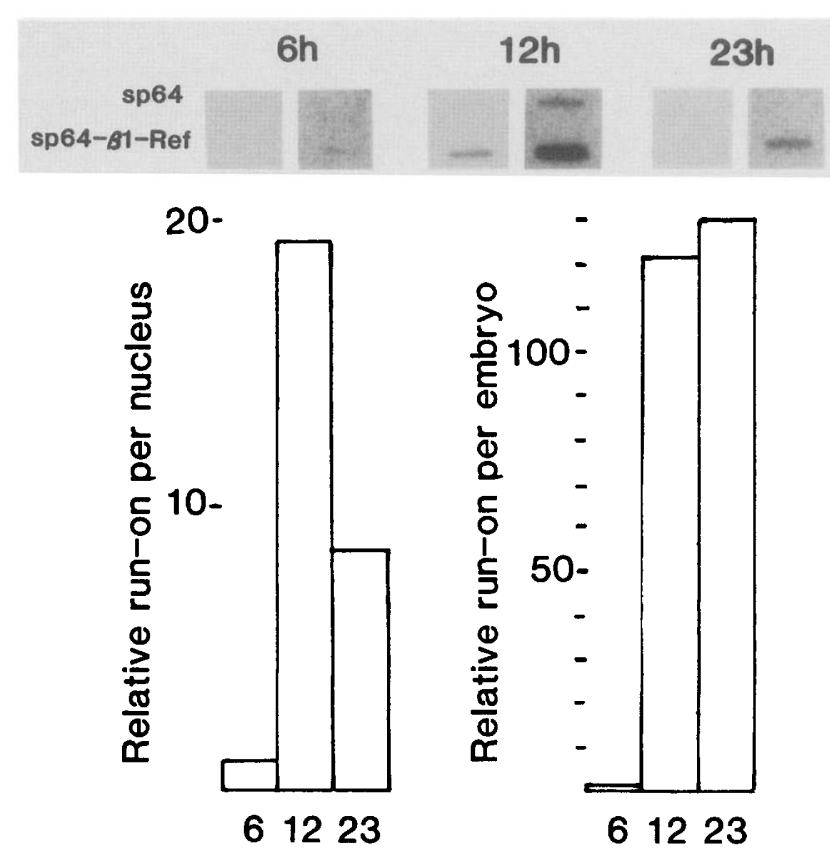

Hours Postfertilization

Figure 8. Relative transcription rates of the $\beta$-tubulin genes in nuclei from 6-hr morula, 12-hr early blastula, and 23-hr mesenchyme blastula. Run-on transcripts were elongated with $\left.{ }^{32} \mathrm{P}\right] \mathrm{UTP}$ in equal numbers of nuclei for each stage as described in the Materials and methods. Purified run-on transcripts, $7 \times 10^{5}$ Cerenkov cpm from each reaction, representing $2.7 \times 10^{7}, 1.4 \times 10^{7}$, and $1.1 \times 10^{7}$ nuclei from $6-, 12-$, and 23-hr embryos, respectively, were hybridized to separate slot blots of pSP64- $\beta 1$-Ref DNA and pSP64 DNA, under excess probe conditions, to assure the complete reaction of all $\beta$-tubulin RNA. The slots were exposed for autoradiography for 3 (left side), then 30 (right side) days. From densitometric measurements we calculated the $\beta$-tubulin RNA run-on per nucleus (left bar graph) relative to that of the 6-hr embryo, taken as unity. The run-on rates per embryo (right bar graph) relative to the 6-hr stage as unity were calculated from the number of cells per embryo $(32,200$, and 500 at the 6-, 12-, and $23-\mathrm{hr}$ stages, respectively). 


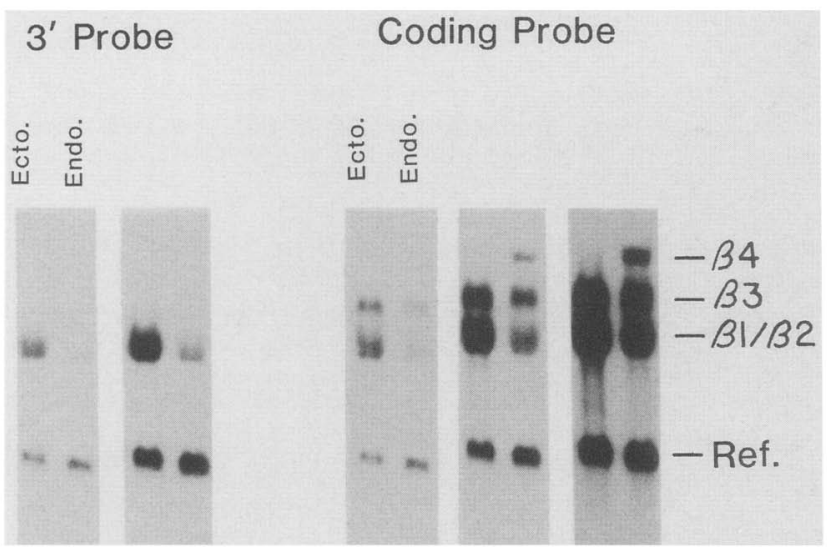

Figure 9. Specificity of $\beta$-tubulin mRNA expression in pluteus ectoderm and endomesoderm tissue fractions. Pluteus larvae were fractionated into ectoderm (Ecto.) and endomesoderm (Endo.) tissue fractions. A mixture of total RNA (7 $\mu \mathrm{g} / \mathrm{lane}$ ) from each of these fractions and $62.5 \mathrm{pg}$ of ${ }^{3} \mathrm{H}$-labeled reference RNA was electrophoresed, then blotted onto nitrocellulose. The gel blot was hybridized successively with the $\beta 13^{\prime}$-specific probe and then the coding-region probe, as in Fig. 3. Exposures of 4 and $12 \mathrm{hr}$ for the $\beta 13^{\prime}$-specific probe and exposures of 4,12 , and $60 \mathrm{hr}$ for the coding-region probe are shown.

spectively, over the endomesoderm. In contrast, there is little if any $\beta 4$ mRNA detectable in the ectoderm, resulting in a 13-fold enrichment of $\beta 4$ mRNA in the endomesoderm fraction. The tissue-specific enrichment of $\beta$-tubulin mRNAs is comparable to that of the Spec mRNAs (Bruskin et al. 1981), e.g., Spec 3 mRNA was recorded as being 14- to 20-fold enriched in the pluteus ectoderm.

The potential significance of $\beta$-tubulin tissue specificities Although the expression of certain individual $\beta$ tubulin genes is emphasized in specific tissues (Havercroft and Cleveland 1984), exclusive expression in a single cell type has not been demonstrated, except in the case of a divergent erythrocyte $\beta$-tubulin (Murphy and Wallis 1983). In the case of the sea urchin pluteus, widely different degrees of discrimination are apparent: Whereas the expression of $\beta 2$ and $\beta 3$ tubulin genes is higher by a small factor in the ectoderm compared with the endomesoderm fraction, the expression of the $\beta 1$ gene is almost exclusively ectodermal and that of the $\beta 4$ gene is, to the same degree, exclusively endomesodermal. The contrasting tissue specificities of the $\beta 1$ and $\beta 4$ tubulin genes may be considered in connection with the divergence in their respective coding region sequences, indicated by the melting differences of their hybrids with the $\beta 1$ coding probe. This probe includes the sequence (amino acids 288-377) encoding the amino-terminal portion of the carboxyl domain of the $\beta$-tubulin polypeptide (Mandelkow et al. 1985). Although this portion of the molecule does not include the extreme carboxyl terminus, which has been postulated to distinguish four isotypic classes of $\beta$-tubulin (Sullivan and Cleveland 1986), this region has some heterogeneity among the amino acid sequences of the $\beta$-tubulin isotypes. The divergence in nucleotide sequences of $\beta 1$ and $\beta 4$ may, thus, indicate amino acid sequence differences and potentially distinct, tissue-specific $\beta$-tubulin isotypes. However, since a divergent chicken-yeast chimeric $\beta$-tubulin appears to function normally in microtubules of mouse 3T3 cells (Bond et al. 1986), various isotypes may not define specific microtubular functions. Unless isotype interchanges are shown to pose functional restraints in more highly differentiated cell types, tissue-specific expression of members of this gene family may be seen principally as a means for specific quantitative regulation.

Certain similarities in developmental and tissue-specific expression suggest that there may be some degree of coordination between $\beta$-tubulin and actin genes (Cox et al. 1986; Lee et al. 1986), both of which encode cytoskeletal proteins. The CyIIIa actin and $\beta 1$ tubulin mRNAs are similar in abundance and are highly enriched in the pluteus ectoderm. They have similar programs of developmental accumulation, with $\beta 1$ tubulin mRNA beginning to accumulate between the morula and early blastula stages and CyIIIa actin appearing some $2-3 \mathrm{hr}$ later in the early blastula (Shott et al. 1984; Nemer 1986). The tissue specificity of CyIla actin mRNA, which appears in the mesenchyme in the gastrula and in the gut of the pluteus (Cox et al. 1986), resembles that of $\beta 4$ tubulin mRNA, insofar as the latter is found in the pluteus endomesodermal tissue fraction comprising both structures. Moreover, both of these mRNAs, which are relatively rare among the transcripts of their respective families, do not accumulate until later embryonic stages: CyIla actin mRNA after the mesenchyme blastula stage, and $\beta 4$ tubulin mRNA in the late-stage gastrula. The appearance of $\beta 4 \mathrm{mRNA}$ occurs long after cytoplasmic cables containing microtubules have arisen between mesenchyme cells and the formation of spicules (Gibbons et al. 1969). Since tubulin synthesis is conspicuously absent from these mesenchyme cells (Harkey and Whitely 1983), it is likely that $\beta 4$ tubulin mRNA is also absent and is present only in the gut of the late-stage embryo. Although precise localization of individual $\beta$-tubulin gene expression awaits the construction of additional gene-specific probes, our results support the hypothesis that certain members of these respective cytoskeletal gene families are coordinated in their tissue-specific expression.

\section{Conclusions}

A unique $\beta$-tubulin gene $(\beta 1)$ has been identified among a total of $9-12 \beta$-tubulin genes in the $S$. purpuratus genome, through the use of $\beta 1$-specific $3^{\prime}$ untranslated and common $\beta$-tubulin coding-region probes derived from a previously sequenced $\beta$-tubulin cDNA, Sp- $\beta 1$ (Harlow and Nemer, in prep.).

At least four different $\beta$-tubulin RNAs have been found in $S$. purpuratus embryos. A 1.8-kb $\beta 1$-tubulin mRNA was detected by the $\beta 13^{\prime}$-specific probe, while another $1.8-\mathrm{kb}$ mRNA, designated $\beta 2$, and the $2.5-\mathrm{kb} \beta 3$ 
and 3.0-kb $\beta 4$ mRNAs were detected by the coding-region probe. Thermal denaturation studies utilizing the coding-region probe indicate that these RNAs are transcribed from at least three different $\beta$-tubulin genes.

The $\beta$-tubulin mRNAs were quantified by probing them on gel blots together with known molecular equivalents of a reference RNA. Although the $\beta 1, \beta 2$ and $\beta 3$ mRNAs display peak concentrations in the blastula and pluteus stages, only the concentration of $\beta 3$ is higher in the pluteus than in the blastula. In contrast, $\beta 4$ mRNA, the lowest in abundance, is not detected until the gastrula stage. The concentrations of total $\beta$-tubulin mRNA are directly correlated with the rates of $\beta$-tubulin protein synthesis in the early stages. The total of about $3 \times 10^{5}$ molecules of $\beta$-tubulin mRNA in the blastula would support a calculated rate of $\beta$-tubulin protein synthesis of about $3.6 \mathrm{pg} / \mathrm{hr}$ per embryo, which is substantially higher than the value of $0.4 \mathrm{pg} / \mathrm{hr}$ per embryo in the cleavage-stage embryo.

An increased rate of $\beta$-tubulin gene transcription during the cleavage-early blastula transition indicates that the early blastula-stage accumulation of $\beta$-tubulin mRNA is transcriptionally regulated. However, since the $\beta$-tubulin gene transcription rate per embryo does not change during subsequent development through the blastula stages, the observed decrease in the level of $\beta$ tubulin mRNA during this period cannot be attributed to a change in the rate of synthesis, but to post-transcriptional events. We conclude that there is a developmental shift in the predominant mode of regulation from transcriptional to post-transcriptional which probably involves a decrease in the stability of the $\beta$-tubulin mRNAs.

The $\beta$-tubulin mRNAs display different types and degrees of tissue specificity. The $\beta 2$ and $\beta 3$ mRNAs are moderately enriched (respectively, five- and threefold) per unit RNA mass in the pluteus ectoderm relative to the endomesoderm tissue fraction. However, $\beta 1$ mRNA, 17 -fold higher in the ectoderm, is highly ectoderm specific. In contrast, $\beta 4$ mRNA is 13 -fold enriched in the endomesoderm. Therefore, $\beta 1$ and $\beta 4$ mRNAs represent unusual degrees of exclusive expression of $\beta$-tubulin genes in different embryonic tissue types. Similarities in developmental profiles and tissue specificities between these $\beta$-tubulin mRNAs and counterpart transcripts of the actin gene family suggest that counterpart genes in these cytoskeletal protein families may be related in their modes of regulation in the $S$. purpuratus embryo.

\section{Materials and methods}

\section{Embryos and embryo RNA}

Conditions for the culture of $S$. purpuratus embryos in synthetic seawater have been described previously (Nemer et al. 1984). The procedure of McClay and Chambers (1978) was used for the preparation of ectodermal and endomesodermal tissue fractions from plutei. Total RNA was extracted from embryos or tissue fractions, as described by Nemer et al. (1984). RNA sizes were determined from their mobilities on Northern blots by comparison with sea urchin $18 \mathrm{~S}$ and $26 \mathrm{~S}$ rRNAs, $1.8 \mathrm{~kb}$ and $3.6 \mathrm{~kb}$, respectively (Bieber et al. 1981), detected with Meth- ylene Blue (Maniatis et al. 1982) and a synthetic reference RNA (931 bases, described below), detected by hybridization with labeled probe.

\section{Bacteria and plasmids}

The $\beta 1$ cDNA, which has been sequenced (Harlow and Nemer, in prep.) was obtained from the pSpB cDNA library in pBR322, representing $S$. purpuratus blastula polysomal RNA (Shepherd et al. 1983). This 1.3-kb cDNA, previously designated Blast J1 (Nemer 1986), was subcloned into the PstI site of pUC19 by standard procedures (Maniatis et al. 1982) using competent JM83 cells (Morrison 1979). A coding-region probe was prepared by ligating the SacI-SacI fragment of this pUC19- $\beta 1$ plasmid into SacI-digested pSP64 plasmid. The plasmid orientated to produce an anti-sense probe was designated pSP64- $\beta 1$-coding. A $\beta 1$-specific probe, representing its $3^{\prime}$ untranslated sequence, was prepared through a series of subcloning steps, starting with the EcoRI-BamHI fragment from pUC19- $\beta 1$. This fragment was inserted into EcoRI-BamHI-digested pUC19. From this insert an EcoRI-PstI fragment was obtained, digested with TaqI, subsequently ligated to EcoRI-AccI-digested pUC19, and finally subcloned into pSP65, using the EcoRI-HindIII sites. This plasmid was designated pSP65- $\beta 133^{\prime}$. To prepare the template for synthesizing the reference RNA, the EcoRI-BglII fragment was isolated from pBR322- $\beta 1$ and ligated to EcoRI-BamHI-digested pSP64. This plasmid was designated pSP64- $\beta 1-$ Ref. Plasmids were isolated by the alkali lysis method (Birnboim and Doly 1979) and large-scale preparations were further purified by equilibrium cesium chloride density gradient centrifugation.

\section{Synthesis and isolation of RNA probes}

HindIII-digested pSP65- $\beta 13^{\prime}$ and EcoRI-digested pSP64- $\beta 1$ coding were used to synthesize run-off transcripts as anti-sense probes with SP6 RNA polymerase, as described by Melton et al. (1984), except that the final reactions included $10 \mathrm{~mm} \mathrm{NaCl}, 11$ $\mu \mathrm{M}\left[\alpha^{-32} \mathrm{P}\right] \mathrm{UTP}(410 \mathrm{Ci} / \mathrm{mmole}$, Amersham), $75 \mu \mathrm{g} / \mathrm{ml}$ of linearized template DNA, and $375 \mathrm{U} / \mathrm{ml}$ of SP6 RNA polymerase (Promega Biotec). Reaction mixtures $(20-40 \mu l)$ were incubated at $40^{\circ} \mathrm{C}$ for $2 \mathrm{hr}$. Yeast tRNA to a concentration of $5 \mathrm{mg} / \mathrm{ml}$ and RNase-free DNase (Promega Biotec) to a concentration of 1.5 $\mathrm{U} / \mu \mathrm{g}$ of template DNA were added and the reactions incubated at $37^{\circ} \mathrm{C}$ for $20 \mathrm{~min}$. Following extraction with phenol-chloroform, the $\left[{ }^{32} \mathrm{P} \mid \mathrm{RNA}\right.$ was ethanol precipitated. To separate the full-length transcripts from longer, plasmid-directed transcripts, which apparently hybridize to sea urchin rRNA, and any incomplete transcripts, the precipitated RNA was dissolved in $50 \%$ formamide, $5 \mathrm{~mm}$ EDTA, $0.05 \%$ xylene cyanol, $0.05 \%$ Bromophenol Blue, heated to $65^{\circ} \mathrm{C}$ for $5 \mathrm{~min}$ and electrophoresed on a $3 \%$ acrylamide $-8 \mathrm{M}$ urea gel. Brief autoradiography revealed the position of the full-length transcript. This portion of the gel was cut out and the RNA eluted into $10 \mathrm{mM}$ Tris- $\mathrm{HCl}$ (pH 7.5), $5 \mathrm{~mm}$ EDTA, $0.1 \%$ SDS for $12-16 \mathrm{hr}$ at $70^{\circ} \mathrm{C}$ with several changes of buffer. Typically, $250 \mathrm{ng}$ of gel-purified probe with a specific activity of $7 \times 10^{8}$ to $9 \times 10^{8} \mathrm{cpm} / \mu \mathrm{g}$ were obtained.

\section{Synthesis and isolation of the synthetic reference RNA}

The reference RNA, a sense strand containing the sequences of the $\beta 13$ '-specific and coding-region probes, was synthesized as a run-off transcript from EcoRI-digested pSP64- $\beta 1$-Ref DNA. The procedure was the same as above, except that $\left[8-{ }^{3} \mathrm{H}\right] \mathrm{GTP}$ (13 $\mathrm{Ci} / \mathrm{mmole}, \mathrm{ICN})$ was diluted with unlabeled GTP to a spe- 
cific activity of $5.2 \mathrm{Ci} / \mathrm{mmole}$ and used at a final concentration of $100 \mu \mathrm{M}$. After phenol-chloroform extraction, the RNA was purified from unincorporated nucleotides by chromatography on Bio-Gel $1.5 \mathrm{M}$. The peak fractions in the excluded volume were ethanol precipitated. Typically, 3-4 $\mu$ g of $\left[{ }^{3} \mathrm{H}\right]$ RNA with a specific activity of $7.5 \times 10^{6}$ disintegrations/ $\mu \mathrm{g}$ was obtained. The RNA was dissolved in sterile water and stored at $-70^{\circ} \mathrm{C}$. Dilutions were made in $0.2 \mathrm{mg} / \mathrm{ml}$ yeast tRNA. For accurate quantification the $\left[{ }^{3} \mathrm{H}\right]$ RNA of the stated specific activity was stable for greater than 2 weeks and less than 4 weeks; however, the stability can be substantially increased by employing a lower specific activity.

\section{Analysis of RNA levels by the reference RNA method}

Procedures for the electrophoresis of RNA and blotting of formaldehyde gels have been described previously (Nemer et al. 1984), except that $1 \mu l$ of serial dilutions of $\left[{ }^{3} \mathrm{H}\right]$ reference RNA was added to the sample mixture prior to heating to $65^{\circ} \mathrm{C}$. Northern blots were prehybridized $3-5 \mathrm{hr}$ at $44^{\circ} \mathrm{C}$ in the presence of $50 \%$ formamide, $5 \times \mathrm{SSC}, 50 \mathrm{~mm}$ phosphate buffer $(\mathrm{pH}$ 7), $7.5 \times$ Denhardt's solution (Denhardt 1966), $0.1 \%$ sodium pyrophosphate, $0.1 \%$ SDS, $1 \mathrm{~mm}$ EDTA, $0.2 \mathrm{mg} / \mathrm{ml}$ yeast RNA, and $0.1 \mathrm{mg} / \mathrm{ml}$ denatured salmon sperm DNA. Hybridization with RNA probes was performed for $12-14 \mathrm{hr}$ at $44^{\circ} \mathrm{C}$ in fresh prehybridization solution in which the Denhardt's solution was decreased to $5 \times$ and the yeast RNA was increased to 0.3 $\mathrm{mg} / \mathrm{ml}$. Typically, each gel blot (about $170 \mathrm{~cm}^{2}$ ) was incubated with $10^{7} \mathrm{cpm}$ of probe. High-stringency washes were performed in $0.1 \times \mathrm{SSC}, 0.1 \%$ sodium pyrophosphate, $0.1 \%$ SDS at $70^{\circ} \mathrm{C}$. Routinely, gel blots were initially hybridized with the $\beta 13^{\prime}$ probe, washed, and autoradiographed. After the probe was removed from the filter in $0.01 \%$ SDS at $95-100^{\circ} \mathrm{C}$ for $10 \mathrm{~min}$, the gel blot was hybridized with the coding-region probe. The number of $\beta 1$ RNA molecules was calculated directly by comparing the $\beta 13^{\prime}$ signal in the 1.8 -kb band with that in a known amount of the $0.93-\mathrm{kb}$ reference RNA on the same Northern. Similarly, using appropriate exposures, the number of $\beta 3$ and $\beta 4$ RNA molecules was calculated by comparing the codingprobe signals in the $2.5-\mathrm{kb}$ band $(\beta 3)$ and the $3.0-\mathrm{kb}$ band $(\beta 4)$ with the coding-probe signal in the reference RNA band. Since $\beta 2$ RNA was not resolved from $\beta 1$ RNA when probed with the coding probe, $\beta 2$ RNA was determined by calculating the total amount of $\beta$-tubulin RNA in the 1.8 -kb band as detected by the coding-region probe and subtracting the amount of $\beta 1$ RNA determined using the $\beta 13^{\prime}$-specific probe. To correct for uniformity of input RNA per lane, the coding-region probe was removed from the blots, which were then hybridized to nicktranslated $\mathrm{pSpBc12}$, equivalent in its restriction map to the mitochondrial ribosomal RNA clone SpP389 (Jacobs et al. 1983). The signal of the 1.4-kb mtRNA band assayed densitometrically served as a gauge of total RNA, since the content of mtRNA is essentially constant during development. The corrected amounts of the four $\beta$-tubulin RNAs could be converted directly into the number of molecules per embryo, since the total amount of RNA per embryo $(3.0 \pm 0.2 \mathrm{ng})$ is essentially constant throughout development (Nemer et al. 1984).

\section{Analysis of RNA levels by solution hybridization}

Tracer excess hybridizations were performed with the purified [32P]RNA probes described above and varying amounts of total RNA isolated from $20-\mathrm{hr}$ blastulae. The procedure described by Lee et al. (1986) was followed, except that hybridization was in the presence of $50 \%$ formamide, $2.5 \times$ SSC, $50 \mathrm{~mm}$ phosphate buffer (pH 7), $1 \mathrm{mM}$ EDTA at $44^{\circ} \mathrm{C}$ for $20 \mathrm{hr}$ and unhybridized tracer was digested with $65 \mu \mathrm{g}$ of RNase A at $37^{\circ} \mathrm{C}$ for $1 \mathrm{hr}$.
Backgrounds of $0.26 \%$ and $0.19 \%$ of input for the $\beta 13^{\prime}$ probe and the $\beta 1$-coding probe, respectively, were subtracted. Slopes of the RNase-resistant cpm versus the total RNA input (microgram) were calculated by a linear least-squares analysis of the data points. To calculate the mass of mRNA (picograms/embryol, we used the equation, $x y / \alpha \gamma \delta$, where $x$ is the slope of the titration curve (cpm of probe/ $\mu$ g of total RNA); $y$, the mass of total RNA/embryo (3.0 ng, Nemer et al. 1984); $\alpha$, the ${ }^{32} \mathrm{P}$ scintillation counting efficiency $(97.3 \%) ; \gamma$, the specific activity of the probe (disintegrations/min per $\mathrm{pg}$ ); and $\delta$, the fraction of mature mRNA represented on the probe. The $\beta 13^{\prime}$-specific probe represents 183 bases of a 1.8-kb RNA, while the coding probe represents 277 bases of the average $\beta$-tubulin mRNA of $2.0 \mathrm{~kb}$. The number of molecules/embryo is derived by dividing the picograms of RNA/embryo by the molecular weight of the RNA (picograms/molecule). The use of a higher salt concentration $(5 \times \mathrm{SSC})$ or higher temperature $\left(50^{\circ} \mathrm{C}\right)$ did not alter the solution hybridization results with the $\beta 13^{\prime}$ probe.

\section{Genomic DNA blots}

Separate sperm DNA preparations were made from several individuals according to the procedure described by Lee et al. (1984). Aliquots of these DNA samples were digested to completion with various restriction enzymes and electrophoresed on $0.7 \%$ agarose gels prior to blotting onto nitrocellulose filters by the method of Southern (1975). These filters were prehybridized as described above for the Northern blots. Hybridization with the [ $\left.{ }^{32} \mathrm{P}\right]$ RNA probes was as described above, except that it was extended to $24 \mathrm{hr}$. Initial stringency washes were in $0.5 \times$ SSC, $0.1 \%$ SDS, $0.1 \%$ sodium pyrophosphate at $60^{\circ} \mathrm{C}$. For the $\beta 13^{\prime}$-specific probe high-stringency washes were in $0.3 \times$ SSC at $65^{\circ} \mathrm{C}$. For the coding probe, moderate stringency washes were in $0.3 \times \mathrm{SSC}$ at $65^{\circ} \mathrm{C}$, while high-stringency washes were in $0.1 \times \mathrm{SSC}$ at $70^{\circ} \mathrm{C}$.

\section{Determination of the number of $\beta$-tubulin genes}

HindIII-digested SP64- $\beta 1$-Ref DNA was diluted using HindIIIdigested $\lambda$ DNA as carrier so that amounts of plasmid DNA equivalent to $1,2,3,5,10,15$, and 20 copies of $\beta$-tubulin sequence contained in $1 \mu \mathrm{g}$ of $S$. purpuratus genomic DNA would be loaded per slot as standards. Assuming $0.89 \mathrm{pg}$ of DNA as the haploid genome of $S$. purpuratus (Hinegardner 1974), one haploid genome equivalent is equal to $4.86 \mathrm{pg}$ of pSP64- $\beta 1-$ Ref. Genomic DNA from two of the individuals described above was digested with PstI. Replica filters were prepared, except that the filter for the coding probe contained 0.5 and $1 \mu \mathrm{g}$ of each sample genomic DNA, while the filter for the $\beta 13^{\prime}$-specific probe contained 1 and $3 \mu \mathrm{g}$ of each sample genomic DNA. All DNA samples were denatured in $0.3 \mathrm{M} \mathrm{NaOH}$ at $95^{\circ} \mathrm{C}$ for 1 $\mathrm{hr}$, chilled on ice, neutralized with an equal volume of $2 \mathrm{M}$ ammonium acetate, and immediately loaded onto nitrocellulose slot blots. The filters were baked for $2 \mathrm{hr}$ at $80^{\circ} \mathrm{C}$ in vacuo, prehybridized as described above for the Northerns, hybridized to ${ }^{32} \mathrm{P}$-labeled RNA probes for $24 \mathrm{hr}$ at $44^{\circ} \mathrm{C}$, washed at the indicated stringencies for the genomic blots, and autoradiographed. The genomic samples were compared with the plasmid standards by scanning densitometry.

\section{Nuclear run-on transcription}

Nuclei were isolated from 6-, 12- and 23-hr embryos as described by Marzluff and Huang (1984). The purified nuclear suspension, containing $3.2 \times 10^{7}$ nuclei from each stage, was incubated in a volume of $0.2 \mathrm{ml}$ at $22^{\circ} \mathrm{C}$ for $45 \mathrm{~min}$ under a single set of conditions, previously described (Wilkinson and Nemer 
1987). The rate of incorporation of $\left[\alpha^{-32} \mathrm{P}\right]$ UTP in RNA was monitored through binding to DE-81 filters (Whatman) in $0.5 \mathrm{M}$ $\mathrm{NaHPO}_{4}$, and the labeled RNA was purified as described (Wilkinson and Nemer 1987). To compare the relative rates of transcription of $\beta$-tubulin genes in nuclei from $6-, 12-$, and $23-\mathrm{hr}$ embryos, equal amounts of radioactivity of the recovered nuclear RNA were separately hybridized to an excess amount $(5$ $\mu \mathrm{g}$ ) of linearized SP64- $\beta 1$-Ref plasmid, immobilized on nitrocellulose as a slot blot (see above). This hybridization was in $30 \%$ formamide, $5 \times \mathrm{SSC}, 50 \mathrm{~mm}$ sodium phosphate $(\mathrm{pH} 7.0)$, $5 \times$ Denhardt's solution, $0.1 \%$ SDS, $0.1 \%$ sodium pyrophosphate, $0.2 \mu \mathrm{g} / \mathrm{ml}$ poly(A), $0.5 \mathrm{mg} / \mathrm{ml}$ yeast RNA, $0.1 \mathrm{mg} / \mathrm{ml}$ denatured salmon sperm DNA, at a total volume of $0.5 \mathrm{ml}$ at $44^{\circ} \mathrm{C}$ for $72 \mathrm{hr}$. Following this, the filters were washed at a final stringency of $0.3 \times$ SSC, $0.1 \%$ SDS, $0.1 \%$ sodium pyrophosphate at $50^{\circ} \mathrm{C}$, then treated with $20 \mu \mathrm{g} / \mathrm{ml}$ of RNase A in $0.3 \mathrm{M}$ $\mathrm{NaCl}, 10 \mathrm{~mm}$ Tris- $\mathrm{HCl}(\mathrm{pH} 7.5), 5 \mathrm{mM}$ EDTA at $37^{\circ} \mathrm{C}$ for 30 min, rewashed in $0.3 \times \mathrm{SSC}$ at $50^{\circ} \mathrm{C}$, and subjected to autoradiography. RNase treatment served to reduce noise and to increase the effective stringency, as gauged by treatment of Northern blots with RNase under similar conditions, to a level sufficient to reduce nonspecific hybridization of RNA with SP6 vector sequences, but allow detection of all four $\beta$-tubulin RNAs by the coding sequences contained in the SP64- $\beta 1$-Ref probe.

\section{Acknowledgments}

We are grateful to Elizabeth Watkins and Margaret Campbell for their excellent technical assistance. This investigation was supported by grants from the U.S. Public Health Service, [HD-04367 (M.N.), CA-06927, and RR-05539 (I.C.R.)] and by an appropriation from the Commonwealth of Pennsylvania. P.H. is a postdoctoral trainee supported by National Institutes of Health grant CA-09035-11.

\section{References}

Alexandraki, D. and J.V. Ruderman. 1981. Sequence heterogeneity, multiplicity and genomic organization of $\alpha$ - and $\beta$-tubulin genes in the sea urchins. Mol. Cell. Biol. 1: 1125-1137.

- 1983. Evolution of $\alpha$ - and $\beta$-tubulin genes as inferred by the nucleotide sequences of sea urchin cDNA clones. I. Mol. Evol. 19: 397-410.

- 1985. Expression of $\alpha$ - and $\beta$-tubulin genes during development of sea urchin embryos. Dev. Biol. 109: 436-451.

Baker, E.J., J.A. Schloss, and J.L. Rosenbaum. 1984. Rapid changes in tubulin RNA synthesis and stability induced by deflagellation in Chlamydomonas. I. Cell Biol. 99: 20742081.

Bieber, D., N. Blin, and D. Stafford. 1981. Region of transcriptional initiation in Lytechinus variegatus rRNA genes. Biochem. Biophys. Acta 655: 366-373.

Birnboim, H.C. and J. Doly. 1979. A rapid alkaline extraction procedure for screening recombinant plasmid DNA. Nucleic Acids Res. 7: 1513-1523.

Bond, J.F., J.L. Fridovich-Keil, L. Pillus, R.C. Mulligan, and F. Solomon. 1986. A chicken-yeast chimeric $\beta$-tubulin protein is incorporated into mouse microtubules in vivo. Cell 44: 461-468.

Bond, J.F., G.S. Robinson, and S.R. Farmer. 1984. Differential expression of two neural cell-specific $\beta$-tubulin mRNAs during rat brain development. Mol. Cell Biol. 4: 1313-1319.

Brandis, J.W. and R.A. Raff. 1978. Translation of oogenetic mRNA in sea urchin eggs and embryos. Demonstration of a change in translational efficiency following fertilization. Dev. Biol. 67: 99-113.

Britten, R.J., A. Cetta and E.H. Davidson. 1978. The single-copy DNA sequence polymorphism of the sea urchin Strongylocentrotus purpuratus. Cell 15: 1175-1186

Brunke, K.J., J.G. Anthony, E.J. Sternberg, and D.P. Weeks. 1984. Repeated consensus sequence and pseudopromoters in the four coordinately regulated tubulin genes of Chlamydomonas reinhardi. Mol. Cell Biol. 4: 1115-1124.

Bruskin, A.M., A.L. Tyner, D.E. Wells, R.M. Showman, and W.H. Klein. 1981. Accumulation in embryogenesis of five mRNAs enriched in the ectoderm of the sea urchin pluteus. Dev. Biol. 87: 308-318.

Burland, T.G., T. Schedl, K. Gull, and W.F. Dove. 1984. Genetic analysis of resistance to benzimidazoles in Physarum: Differential expression of $\beta$-tubulin genes. Genetics 108: 123141.

Callahan, R.C., G. Shalke, and M.A. Gorovsky. 1984. Developmental rearrangements associated with a single type of expressed $\alpha$-tubulin gene in Tetrahymena. Cell 36: 441-445.

Caron, J.M., A.L. Jones, L.B. Rall, and M.W. Kirschner. 1985. Autoregulation of tubulin synthesis in enucleated cells. $\mathrm{Na}$ ture 317: 648-651.

Cleveland, D.W., and J.C. Havercroft. 1983. Is apparent autoregulatory control of tubulin synthesis nontranscriptionally regulated? J. Cell Biol. 97: 919-924.

Cleveland, D.W. and K.F. Sullivan. 1985. Molecular biology and genetics of tubulin. Annu. Rev. Biochem. 54: 331-356.

Cleveland, D.W., M.A. Lopata, R.J. MacDonald, N.J. Cowan, W.J. Rutter, and M.W. Kirschner. 1980. Number and evolutionary conservation of $\alpha$ - and $\beta$-tubulin and cytoplasmic $\beta$ and $\gamma$-actin genes using specific cloned cDNA probes. Cell 20: $95-105$.

Cox, K. H., L.M. Angerer, J.J. Lee, E.H. Davidson, and R.C. Angerer. 1986. Cell lineage-specific programs of expression of multiple actin genes during sea urchin embryogenesis. $I$. Mol. Biol. 188: 159-172.

Czihak, G. ed. 1975. The sea urchin embryo. Biochemistry and morphogenesis. Springer-Verlag, Berlin

Davidson, E.H. 1986. Gene activity in early development, 3rd ed. Academic Press, New York.

Denhardt, D.T. 1966. A membrane-filter technique for detection of complementary DNA. Biochem. Biophys. Res. Commun. 23: 641-646.

Elliott, E.M., H. Okayama, F. Sarangi, G. Henderson, and V. Ling. 1985. Differential expression of three $\alpha$-tubulin genes in Chinese hamster ovary cells. Mol. Cell. Biol. 5: 236-241.

Galau, G.A., E.D. Lipson, R.J. Britten, and E.H. Davidson. 1977. Synthesis and turnover of polysomal mRNAs in sea urchin embryos. Cell 10: 415-432.

Gibbons J.R., L.G. Tilney, and K.R. Porter. 1969. Microtubules in the formation and development of the primary mesenchyme in Arbacia punctulata. I. The distribution of microtubules. I. Cell Biol. 41: 201-226.

Giudice, G. 1986. The sea urchin embryo. A developmental biological system. Springer-Verlag, New York.

Goustin, A.S. and F.H. Wilt. 1981. Protein synthesis, polyribosomes, and peptide elongation in early development of Strongylocentrotus purpuratus. Dev. Biol. 82: 32-40.

Groudine, M., M. Peretz, and H. Weintraub. 1981. Transcriptional regulation of hemoglobin switching in chicken embryos. Mol. Cell. Biol. 1: 281-288.

Harkey, M.A. and A.H. Whiteley. 1982. Cell-specific regulation of synthesis in the sea urchin gastrula: A two-dimensional electrophoretic study. Dev. Biol. 93: 453-462.

- 1983. The program of protein synthesis during development of the micromere-primary mesenchyme cell line in 
the sea urchin embryo. Dev. Biol. 100: 12-20.

Havercroft, J.C. and D.W. Cleveland. 1984. Programmed expression of $\beta$-tubulin genes during development and differentiation of the chicken. J. Cell Biol. 99: 1927-1935.

Hinegardner, R. 1974. Cellular DNA content of the echinodermata. Comp. Biochem. Physiol. 49B: 219-226.

Howe, C.C., D.K. Lugg, and G.C. Overton. 1984. Post-transcriptional regulation of the abundance of mRNAs encoding $\alpha$-tubulin and a 94,000 dalton protein in teratocarcinomaderived stem cells versus differentiated cells. Mol. Cell. Biol. 4: 2428-2436.

Infante, A.A. and L.J. Heilmann. 1981. Distribution of messenger ribonucleic acid in polysomes and nonpolysomal particles of sea urchin embryos: Translational control of actin synthesis. Biochemistry 20: 1-7.

Jacobs, H.T., J.W. Posakony, J.W. Grula, J.W. Roberts, J.-H. Xin, R.J. Britten, and E.H. Davidson. 1983. Mitochondrial DNA sequences in the nuclear genome of Strongylocentrotus purpuratus. J. Mol. Biol. 165: 609-632.

Jones, C.W. and F.C. Kafatos. 1982. Accepted mutations in a gene family: evolutionary diversification of duplicated DNA. J. Mol. Evol. 19: 87-103.

Jones, C.W., N. Rosenthal, G.C. Rodakis, and F.C. Kafatos. 1979. Evolution of two major chorion multigene families as inferred from cloned cDNA and protein sequences. Cell 18: $1317-1332$.

Lee, M.G., S.A. Lewis, C.D. Wilde, and N.J. Cowan. 1983. Evolutionary history of a multigene family: An expressed human $\beta$-tubulin gene and three processed pseudogenes. Cell 33: 477-487.

Lee, J.J., R.J. Shott, S.J. Rose III, T.L. Thomas, R.J. Britten, and E.H. Davidson. 1984. Sea urchin actin gene subtypes. Gene number, linkage, and evolution. J. Mol. Biol. 172: 149-176.

Lee, J.J., F.J. Calzone, R.J. Britten, R.C. Angerer, and E.H. Davidson. 1986. Activation of sea urchin actin genes during embryogenesis. Measurement of transcript accumulation from five different genes in Strongylocentrotus purpuratus. J. Mol. Biol. 188: 173-183.

Lewis, S.A., M.E. Gilmartin, J.L. Hall, and N.J. Cowan. 1985a. Three expressed sequences within the human $\beta$-tubulin multigene family each define a distinct isotype. J. Mol. Biol. 182: $11-20$.

Lewis, S.A., M.G. Lee, and N.J. Cowan. 1985b. Five mouse tubulin isotypes and their regulated expression during development. J. Cell Biol. 101: 852-861.

Maniatis T., E.F. Fritsch, and J. Sambrook. 1982. Molecular cloning: A laboratory manual. Cold Spring Harbor Laboratory, Cold Spring Harbor, New York.

Mandelkow, E.M., M. Herrmann, and U. Ruhl. 1985. Tubulin domains probed by limited proteolysis and subunit-specific antibodies. J. Mol. Biol. 185: 311-327.

Martin, K.A. and O.L. Miller, Jr. 1983. Polysome structure in sea urchin eggs and embryos: an electron microscopic analysis. Dev. Biol. 98: 338-348.

Marzluff, W.F. and R.C.C. Huang. 1984. Transcription of RNA in isolated nuclei. In Transcription and translation (ed. B.D. Hames and S.J. Higgins|, pp. 89-129. IRL Press, Oxford.

McClay, D.R., and A.F. Chambers. 1978. Identification of four classes of cell surface antigens appearing at gastrulation in sea urchin embryos. Dev. Biol. 63: 179-186.

Melton D.A., P.A. Krieg, M.R. Rebagliati, T. Maniatis, K. Zinn, and M.R. Green. 1984. Efficient in vitro synthesis of biologically active RNA and RNA hybridization probe from plasmid containing an SP6 promoter. Nucleic Acid Res. 12: $7035-7056$.

Morrison, D.A. 1979. Transformation and preservation of competent bacterial cells by freezing. Methods Enzymol. 68: 326-331.

Murphy, D.B. and K.T. Wallis. 1983. Isolation of microtubule protein from chicken erythrocytes and determination of the critical concentration for tubulin polymerization in vitro and in vivo. J. Biol. Chem. 258: 8357-8364.

Natzle, J.E. and B.J. McCarthy. 1984. Regulation of Drosophila $\alpha-$ and $\beta$-tubulin genes during development. Dev. Biol. 104: $187-198$.

Nemer, M. 1986. An altered series of ectodermal gene expressions accompanying the reversible suspension of differentiation in the zinc-animalized sea urchin embryo. Dev. Biol. 114: 214-224.

Nemer, M., L.M. Dubroff, and M. Graham. 1975. Properties of sea urchin embryo messenger RNA containing and lacking poly(A). Cell 6: 171-178.

Nemer, M., E.C. Travaglini, E. Rondinelli, and J. D'Alonzo. 1984. Developmental regulation, induction and embryonic tissue specificity of sea urchin metallothionein gene expression. Dev. Biol. 102: 471-482.

Posakony, J.W., C.N. Flytzanis, R.J. Britten, and E.H. Davidson. 1983. Interspersed sequence organization and developmental representation of cloned poly(A) RNAs from sea urchin eggs. J. Mol. Biol. 167: 361-389.

Raff, R.A. and J.F. Kaumeyer. 1973. Soluble microtubule proteins of the sea urchin embryo: Partial characterization of the proteins and behavior of the pool in early development. Dev. Biol. 32: 309-320.

Schedl, T., T.G. Burland, K. Gull, and W.F. Dove. 1984. Cell cycle regulation of tubulin RNA level, tubulin protein synthesis, and assembly of microtubules in Physarum. J. Cell Biol. 99: 155-165.

Shepherd, G.W., E. Rondinelli, and M. Nemer. 1983. Differences in abundance of individual RNAs in normal and animalized sea urchin embryos. Dev. Biol. 96: 520-527.

Shott, R.J., J.J. Lee, R.J. Britten, and E.H. Davidson. 1984. Differential expression of the actin gene family of Strongylocentrotus purpuratus. Dev. Biol. 101: 295-306.

Sim, G.K., F.C. Kafatos, C.W. Jones, and M.D. Koehler. 1979. Use of a cDNA library for studies on evolution and developmental expression of the chorion multigene families. Cell 18: $1303-1316$.

Southern, E.M. 1975. Detection of specific sequences among DNA fragments separated by gel electrophoresis. $I$. Mol. Biol. 98: 503-517.

Sullivan, K.F. and D.W. Cleveland. 1986. Identification of conserved isotype-defining variable region sequences for four vertebrate $\beta$-tubulin polypeptide classes. Proc. Natl. Acad. Sci. 83: 4327-4331.

Thomas, T.L., R.J. Britten, and E.H. Davidson. 1982. An interspersed region of the sea urchin genome represented in both maternal poly(A) RNA and embryo nuclear RNA. Dev. Biol. 94: 230-239.

Whiteley, A.H. and S. Mizuno. 1981. Electron microscopic visualization of giant polysomes in sea urchin embryos. Wilhelm Roux's Arch Dev. Biol. 190: 73-82.

Wilkinson, D.G. and M. Nemer. 1987. Metallothionein genes MTa and MTb expressed under distinct quantitative and tissue-specific regulation in sea urchin embryos. Mol. Cell. Biol. 7: 48-58. 


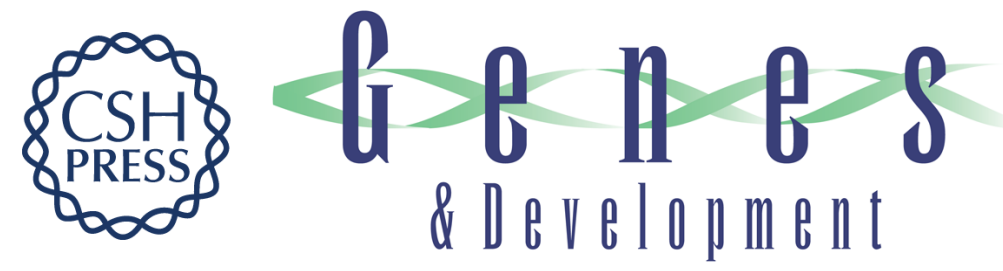

\section{Developmental and tissue-specific regulation of beta-tubulin gene expression in the embryo of the sea urchin Strongylocentrotus purpuratus.}

P Harlow and M Nemer

Genes Dev. 1987, 1:

Access the most recent version at doi:10.1101/gad.1.2.147

References This article cites 60 articles, 16 of which can be accessed free at:

http://genesdev.cshlp.org/content/1/2/147.full.html\#ref-list-1

License

Email Alerting Receive free email alerts when new articles cite this article - sign up in the box at the top Service right corner of the article or click here.

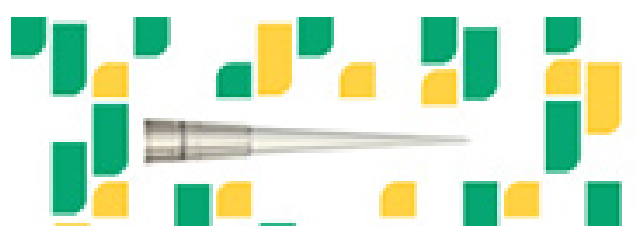

Focused on your science. 